\title{
ERJ
}

Engineering Research Journal

Faculty of Engineering

Minoufiya University

\section{EFFECT OF BED SCOUR AND PILE REFUSAL ON THE BEHAVIOR OF PILES IN WATER COURSES IN EGYPT}

\author{
Y. B. M. Heza \\ Construction Research Institute, National Water Research Center, Cairo, Egypt
}

\begin{abstract}
For construction of bridges in water courses, vertical or nearly vertical driven piles are usually used as the foundation element, because they could be constructed in the presence of water which means quick and cheap construction. Recently, many problems have arisen in several bridge sites using driven piles in water courses. Three such sites have been investigated by the author. A full assessment of those sites was required to avoid the risk of failure. In this paper, the assessment of a case study at the first site is presented and discussed. A comprehensive geotechnical investigation was carried out. Examining the results of the field and laboratory tests showed the presence of a soil layer at the design pile toe level which is very dense and explains the refusal happening while driving the piles. The field investigation also showed that a platform of steel beams and wooden $\operatorname{logs}$ built on wooden piles was used for the pile driving machine in the presence of water. The presence of the platform lead to the contraction of the water course cross section and the contraction gets worse by driving the reinforced concrete piles which in turn lead to a higher water velocity causing scour around the driven piles. Therefore, the stability of the piles became questionable, because of the shorter embedment length due to the refusal of the piles and the scour around them. The stability of the piles under the new conditions in the field was investigated using three criteria; the pile capacity, the buckling length, and the bending moment on the piles. It was shown that pile refusal and the scour reduced the allowable pile capacity. It was also shown that the slender ratio of the piles in 3 supports exceeded the limit defined in the Egyptian code and is unsafe in buckling.

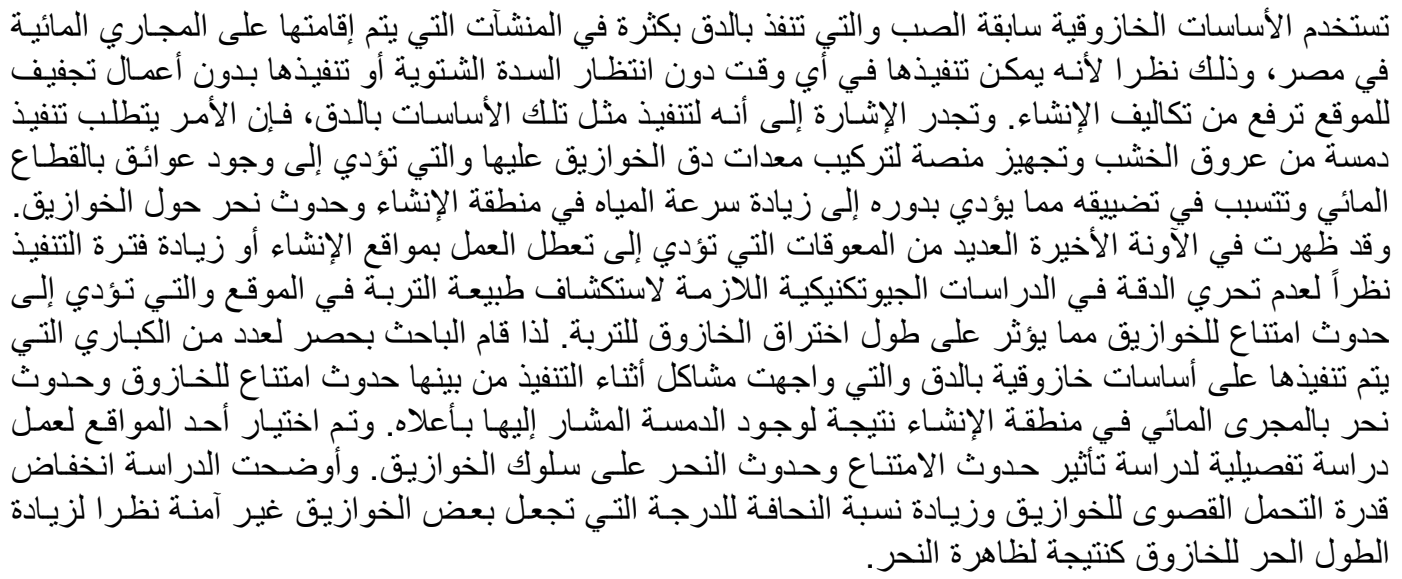

Keywords: Pile foundations, Drag forces, Break forces, Scour, Offshore, Buckling length, Slender ratio, Bending moment, stresses and Bridges

\section{INTRODUCTION}

In Egypt, constructing bridges in the water courses used to follow one of two methods. The first one is to construct the bridge foundation during the winter closure period and the second is to divert the water to either side of the water course, carry out dewatering if necessary, and then construct in the dry condition the abutments and piers as supporting elements to the bridge slab. The disadvantages of these two methods are either waste of time or increased cost because of diversion and dewatering. Therefore, using driven piles as supporting elements has been thought as a better alternative for the quick and cheap construction of bridges in the water courses mainly because they could be constructed in the presence of water. Recently, this practice has lead to many problems in several sites. 
Three sites have been investigated by the author. The first site is the bridge located in Upper Egypt on major canal as shown in figure (1). The soil is consisted of a layer of silty clay followed by poorly graded medium to coarse sand with a lens of gravelly sand. The problem reported in this site is the refusal of the piles at a depth shallower than the required by the design and the presence of scour of about $2.73 \mathrm{~m}$ from the original bed level. The second site is on a branch canal in the North West of Egypt. The soil at the site is mainly cemented sand and the pile penetration depth was shorter by $8 \mathrm{~m}$ because of refusal. The piles are shown in figure (2). The third site is of a bridge on a major canal in the North East of Egypt. The soil is mainly silty clay followed by sandy soil. The problem at the site is the refusal of the piles at a depth shallower than the required by design. Figure (3) shows the piles at the site and the platform used to construct the piles. A full assessment of the sites required to avoid the risk of failure. In this paper, the assessment of the case study at the first site in Upper Egypt is presented and discussed.

Smith (1976) analyzes 143 bridge failures throughout the world between 1875 and 1975; approximately half of the cases were due to floods, most of them due to scour. Rhodes and Trent (1992) evaluated disasters on highways in the USA between 1973 and 1990. Among all possible causes (including vehicle collisions, plane crashes, train derailments, dam and structural failures, earthquakes, fires, landslides, tornados, volcanoes) $75 \%$ of the cases had hydraulic causes. Yeo (1998) reported more than 100 bridges collapsed or badly damaged in Korea annually as an average because of scouring.

Solution of laterally loaded pile has been studied by many authors such as (Robert 1981, Laymon Reese 1977, Mauricio O. and Michael W. 1989, Dunnavnt and O'Neill 1986, Brown et al. 1987, Cox et al. 1984, Holloway et al. 1982, Matlock, H., and Reese, L. 1960). None of them studied the behavior of pile due to the scour that occurs around the pile on the watercourses.

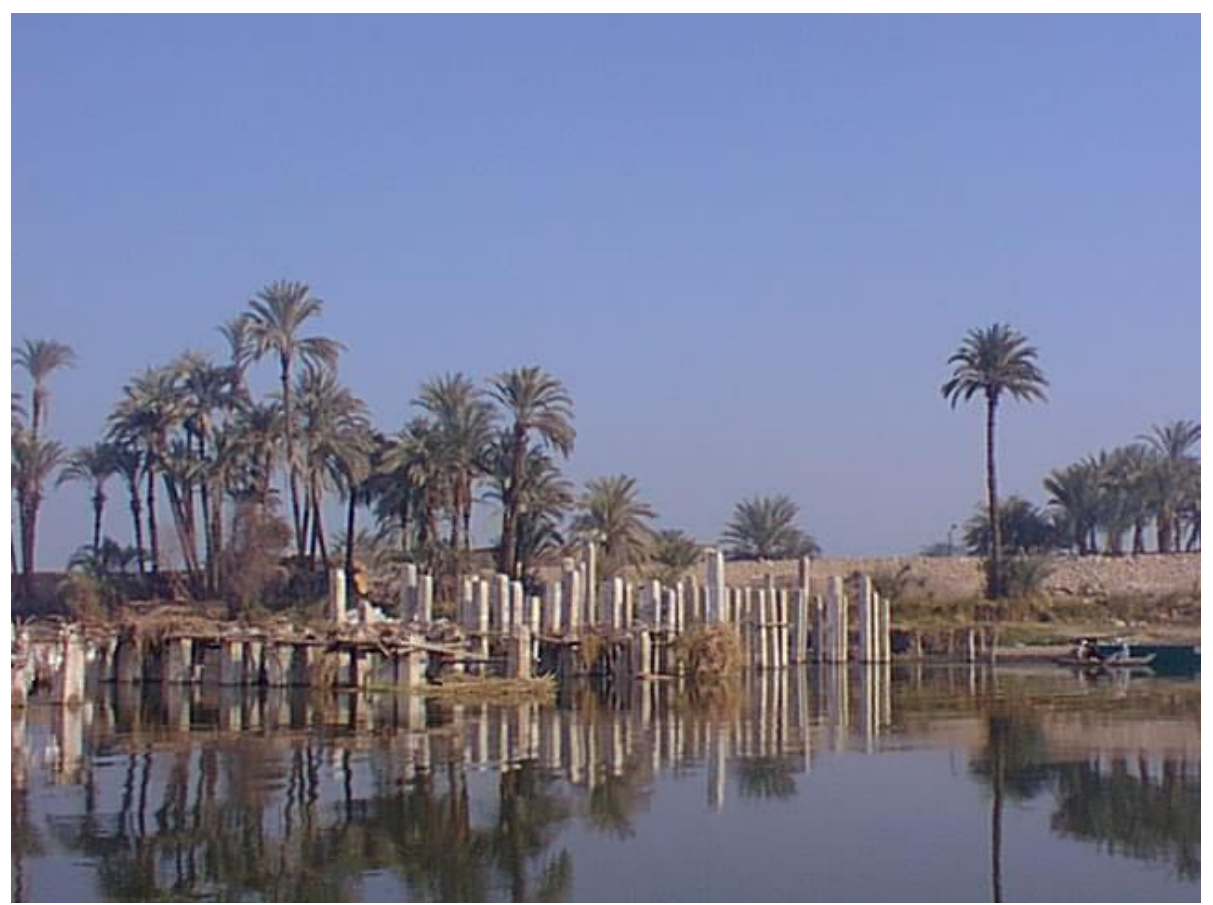

Fig.1 Driven piles of the bridge in Upper Egypt 


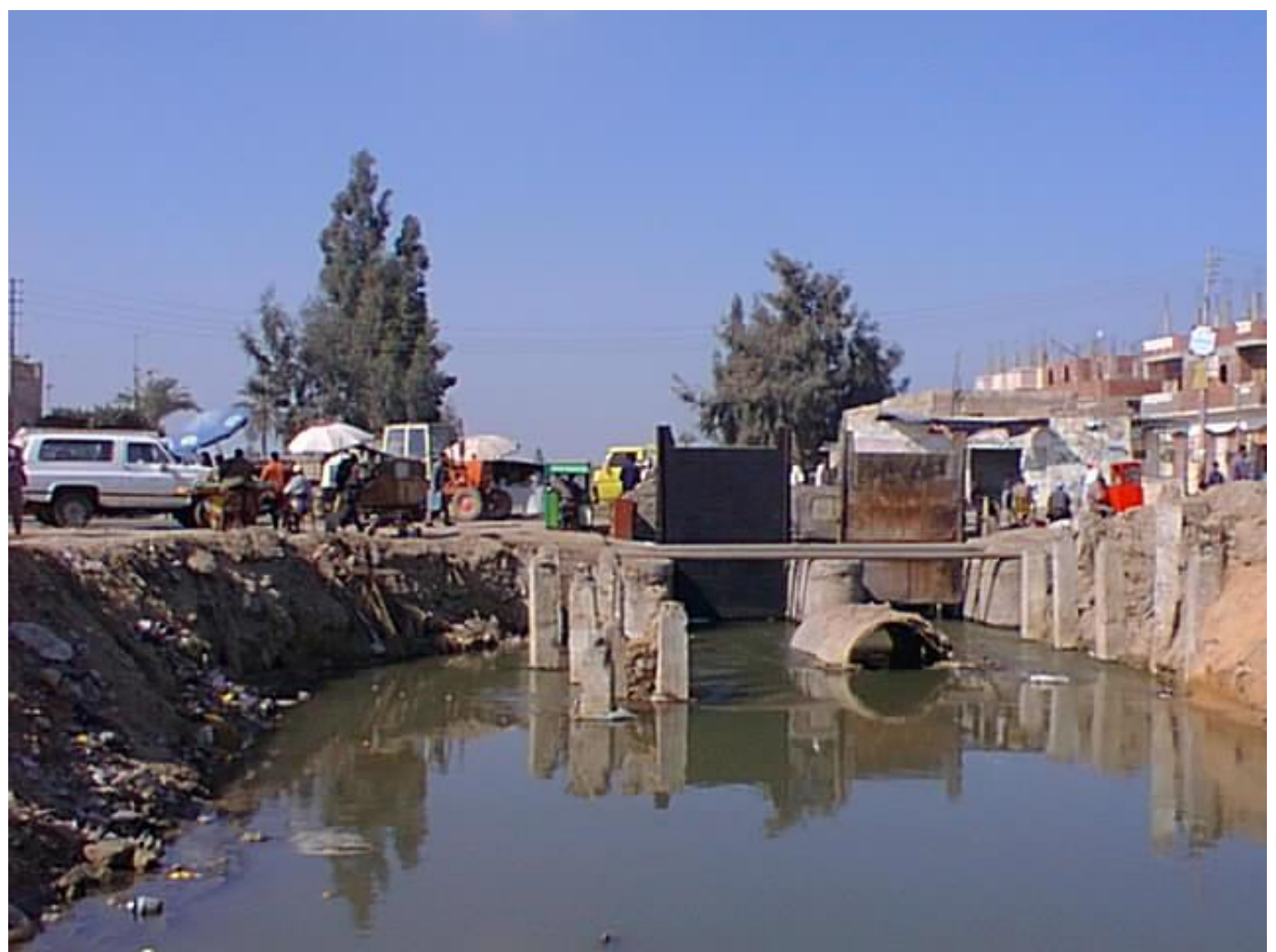

Fig. 2 Driven piles of the bridge in North West of Egypt

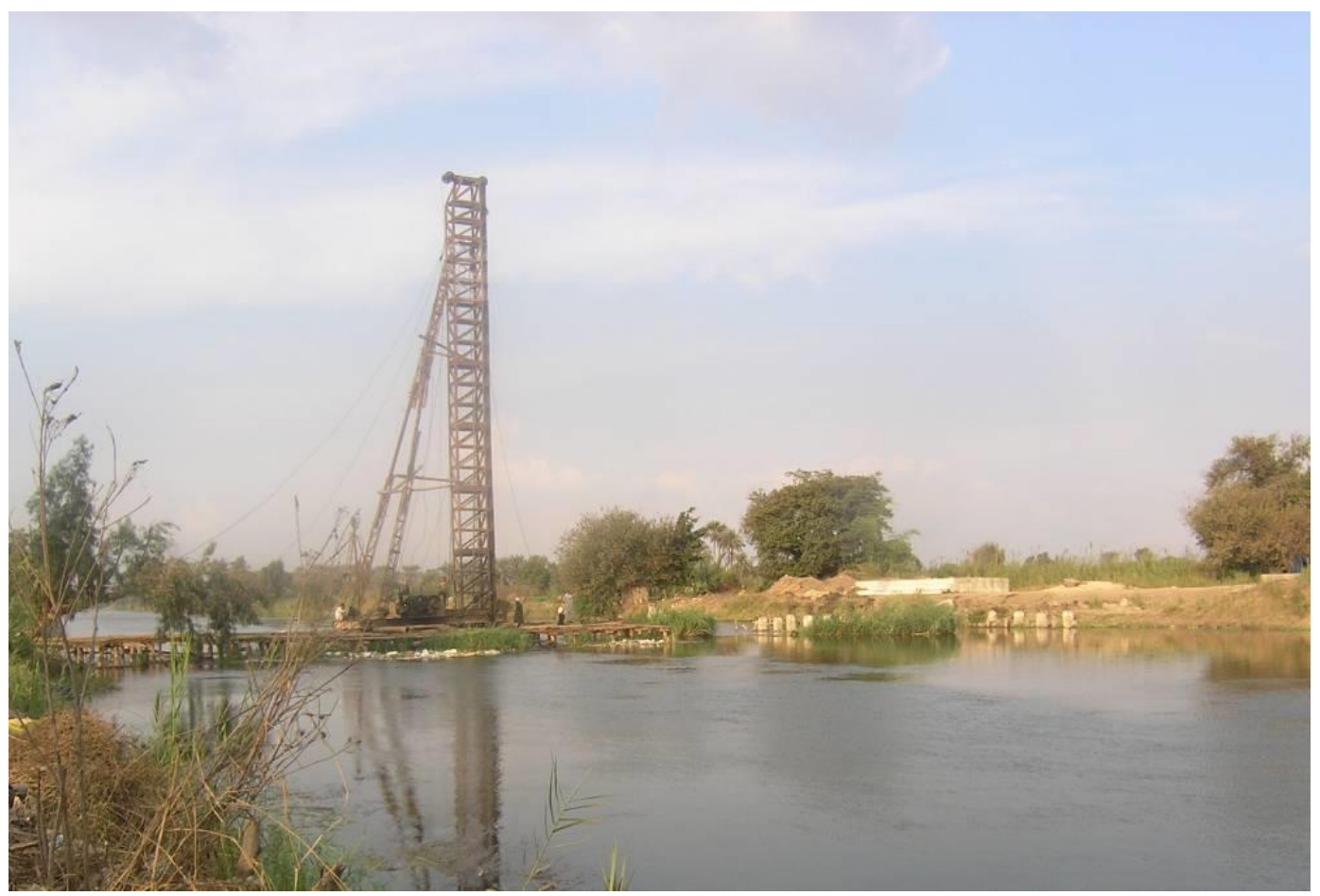

Fig. 3 Driven piles of the bridge in the North East of Egypt 


\section{CASE STUDY}

The case study is the one located on a major canal in Upper Egypt. The bridge of this case is designed to be founded on 8 supports. The right side support is number 1 , the middle supports are number 2, 3, 4, 5, 6 and 7 and the left side support is number 8. Each support is founded on a number of piles with a square cross section of $0.40 \times 0.40 \mathrm{~m}$. For the middle supports, the pile length is $18.0 \mathrm{~m}$, the level under the pile cap is $48.10 \mathrm{~m}$, and the pile toe level is $30.10 \mathrm{~m}$. For the left and right supports, the pile length is $16.0 \mathrm{~m}$, the level under the pile cap is 49.50 $\mathrm{m}$, and the pile toe level is $33.50 \mathrm{~m}$. During the first site visit, all the piles were constructed except for the piles of the right side support.

During construction, most of the piles did not reach to the required toe level as indicted in figures 4 to 9. Consequently, these piles do not satisfy the required embedment length. In addition to that, the observed scour depth in the cross section of the canal at the bridge site after driving the piles ranged from zero to $2.73 \mathrm{~m}$. To investigate the problem, an extensive program of field and laboratory work and numerical analysis were conducted.

\section{FIELD INVESTIGATION}

A comprehensive geotechnical investigation was carried out which included a total of four boreholes; one of them with a depth of $25 \mathrm{~m}$ and the other three with a depth of $15 \mathrm{~m}$. Standard Penetration Tests were conducted and soil samples were extracted. Laboratory tests were carried out to define the required physical, mechanical, and chemical soil prosperities. From the field and laboratory tests, it can be shown that the soil deposit consists mainly of two layers. The top layer is either silty clay or clayey silt with a thickness ranging from $1.0 \mathrm{~m}$ to $13.0 \mathrm{~m}$. The second layer is poorly graded sand till the end of the borehole. A lens of gravelly sand with a thickness of $1.10 \mathrm{~m}$ existed in the third borehole. Figure (10) shows the letheological section across the canal at the bridge site. By examining the results of the field and laboratory tests, it was found that the soil layer at the design pile toe level is very dense which explains the refusal happening while driving the piles. This shows the necessity for accurate geotechnical investigation prior to the design of such structure. Driven piles are not suitable in such a deposit.

The field investigation also showed that a platform of steel beams and wooden logs built on wooden piles was used for the pile driving machine in the presence of water as shown in figure (11). The presence of the platform lead to the contraction of the water course cross section and the contraction gets worse by driving the reinforced concrete piles which in turn lead to a higher water velocity causing scour around the driven piles. Therefore, the stability of the piles became questionable because of the shorter embedment length due to the refusal of the piles and the scour around them. To assess the safety of the driven piles, a stability analysis was conducted.

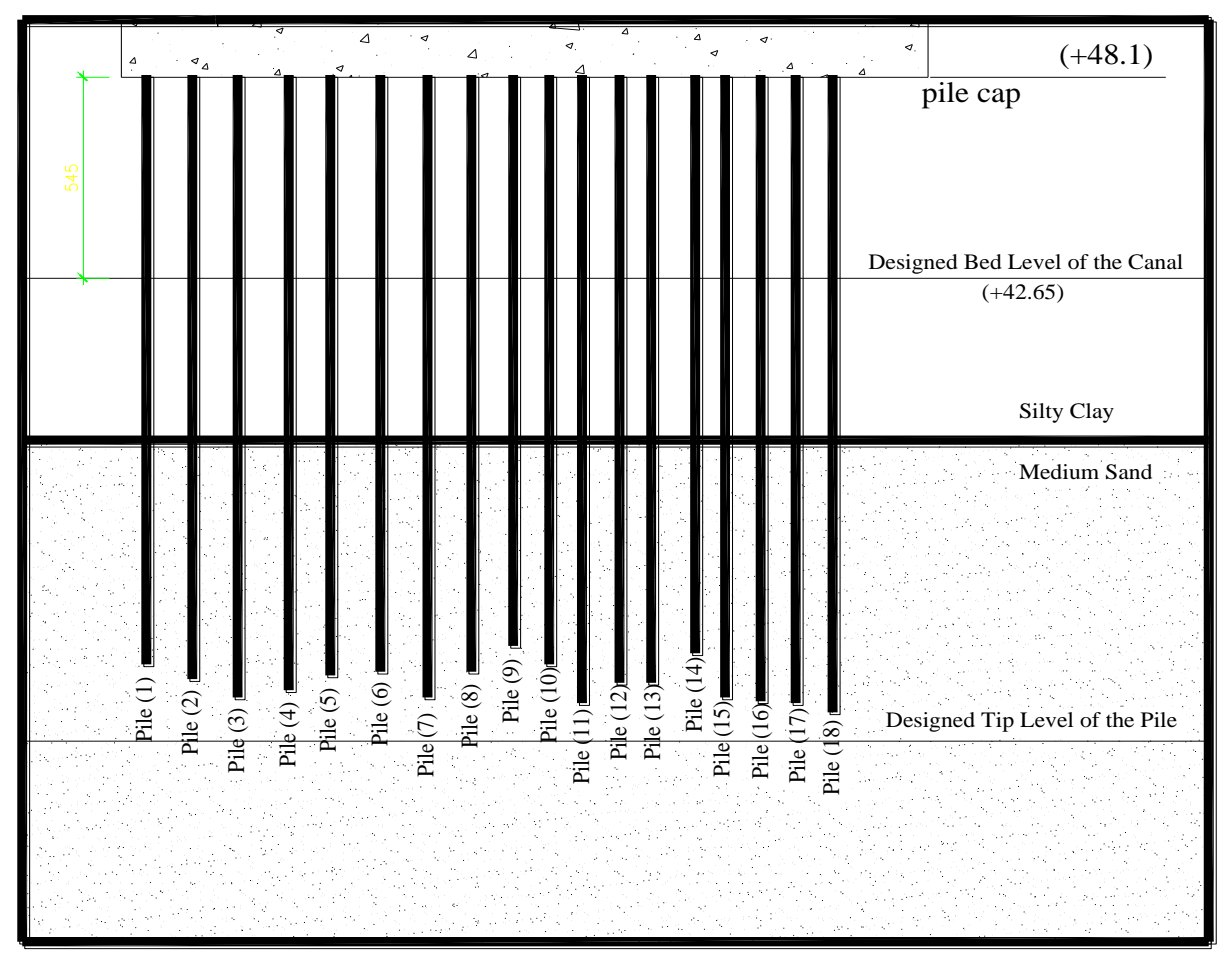

Fig. 4 The embedded length of the driven piles of support no. 2 


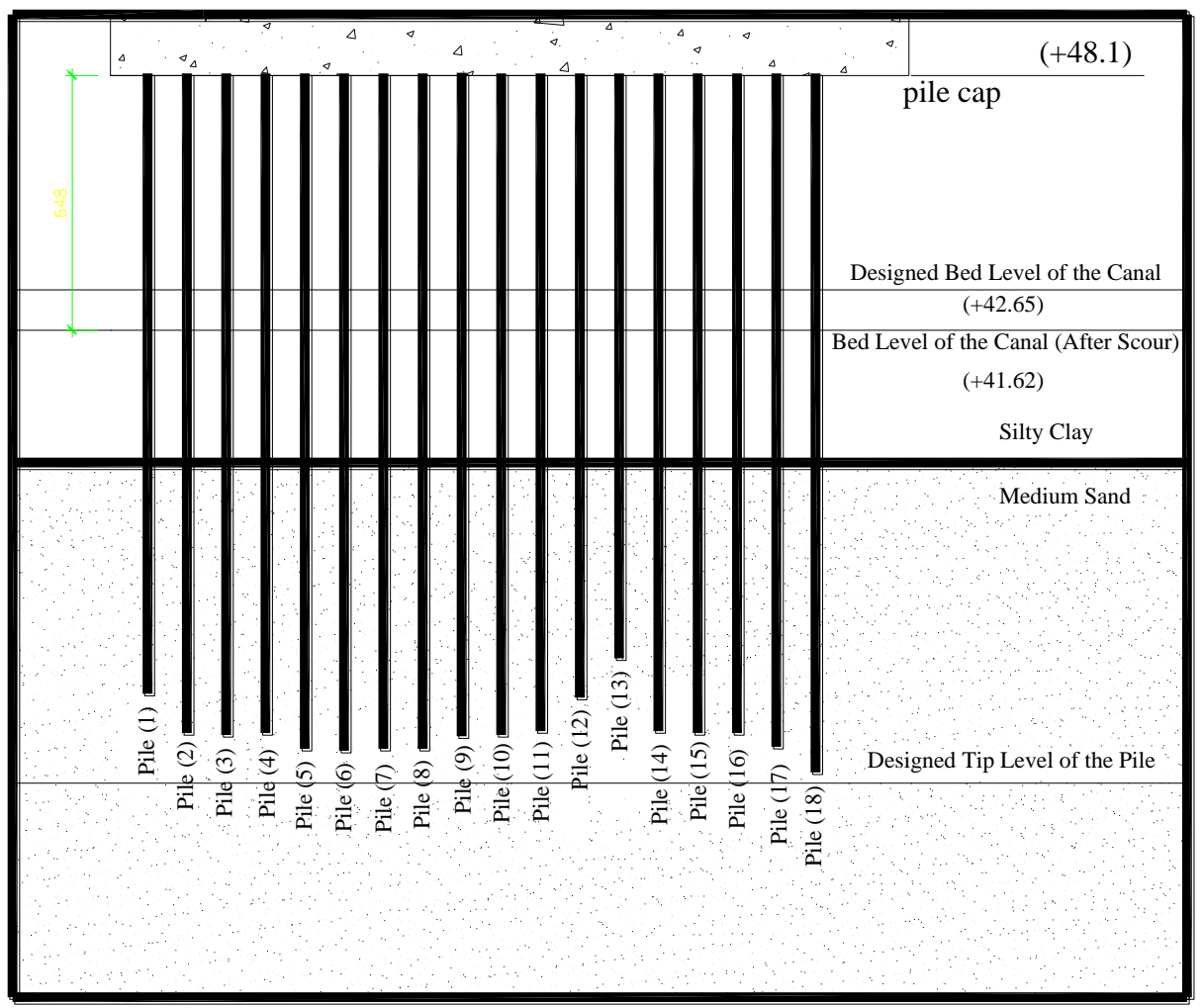

Fig. 5 The embedded length of the driven piles of support no. 3

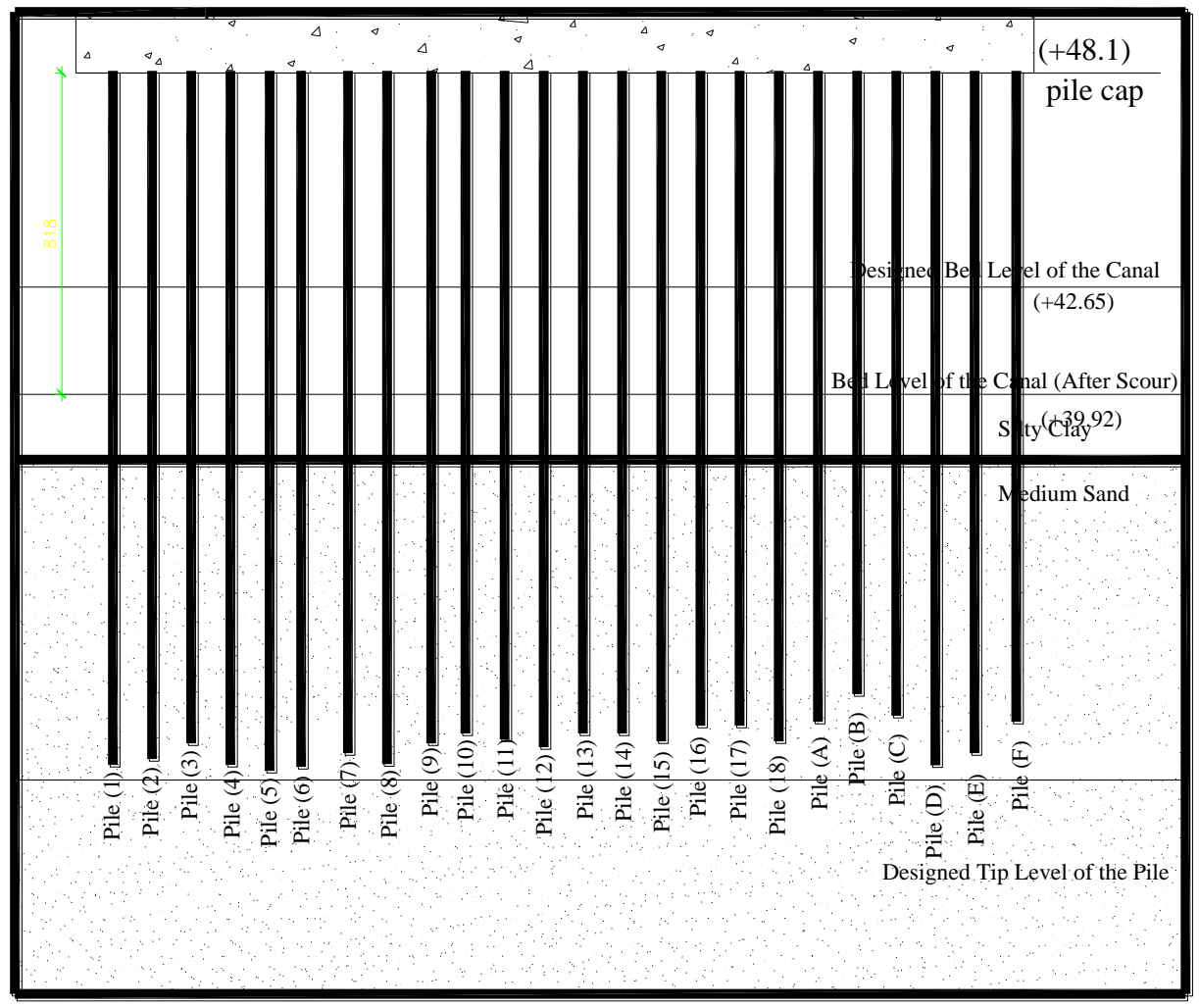

Fig. 6 The embedded length of the driven piles of support no. 4 


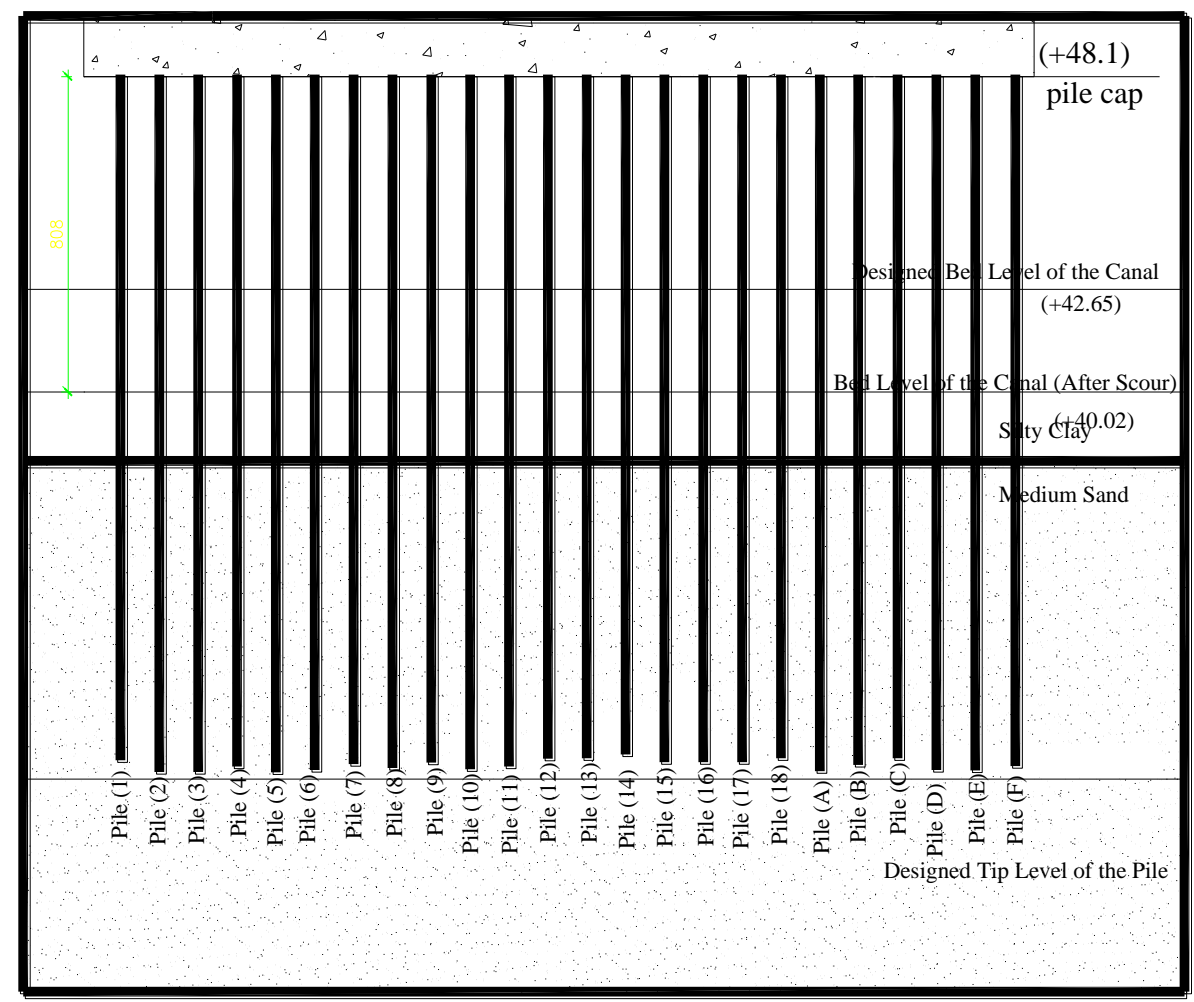

Fig. 7 The embedded length of the driven piles of support no. 5

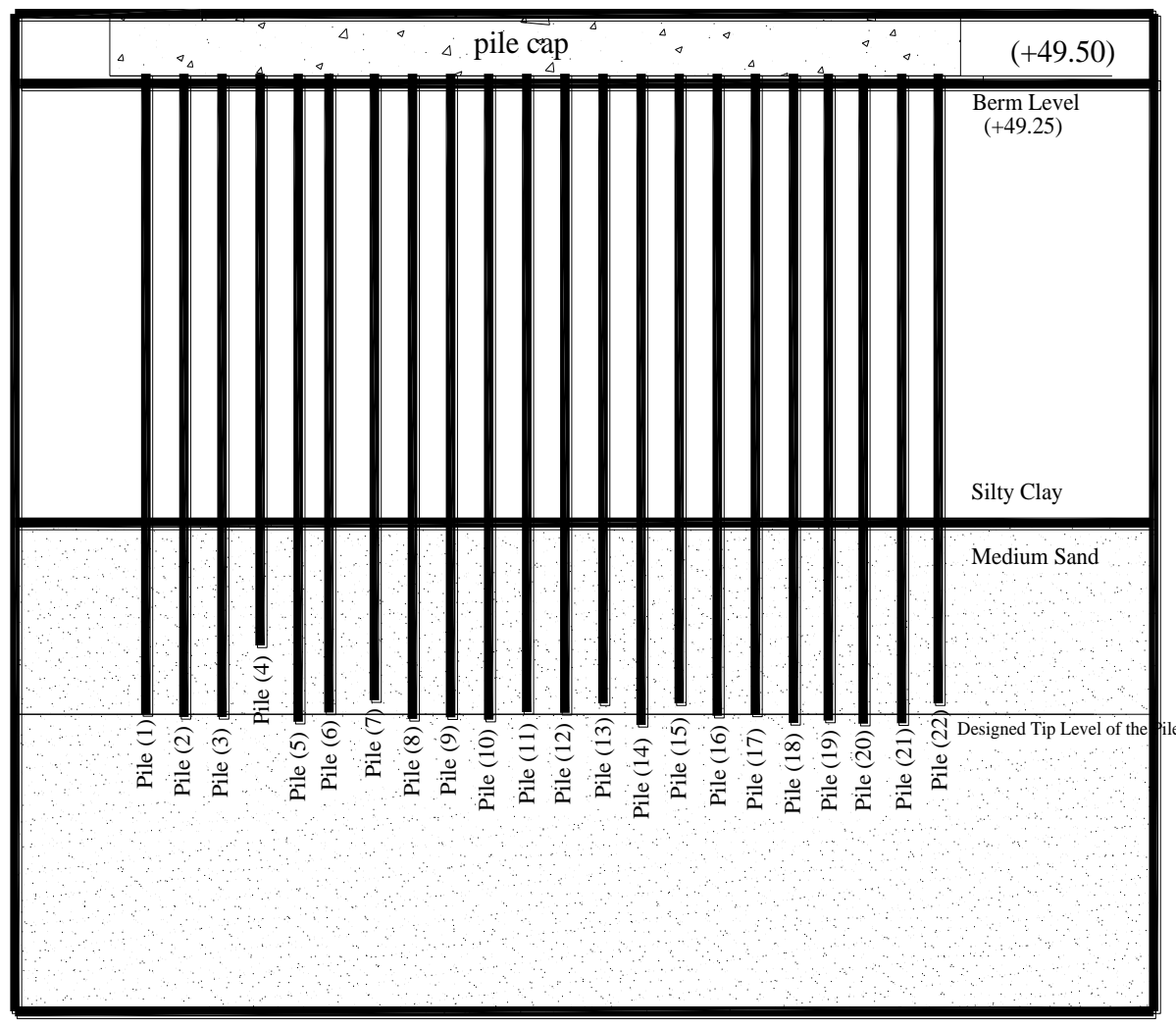

Fig. 8 The embedded length of the driven piles of support no. 6 
Y. B. M. Heza, "Effect of Bed Scour and Pile Refusal on The Behavior of Piles in Water Courses in Egypt"

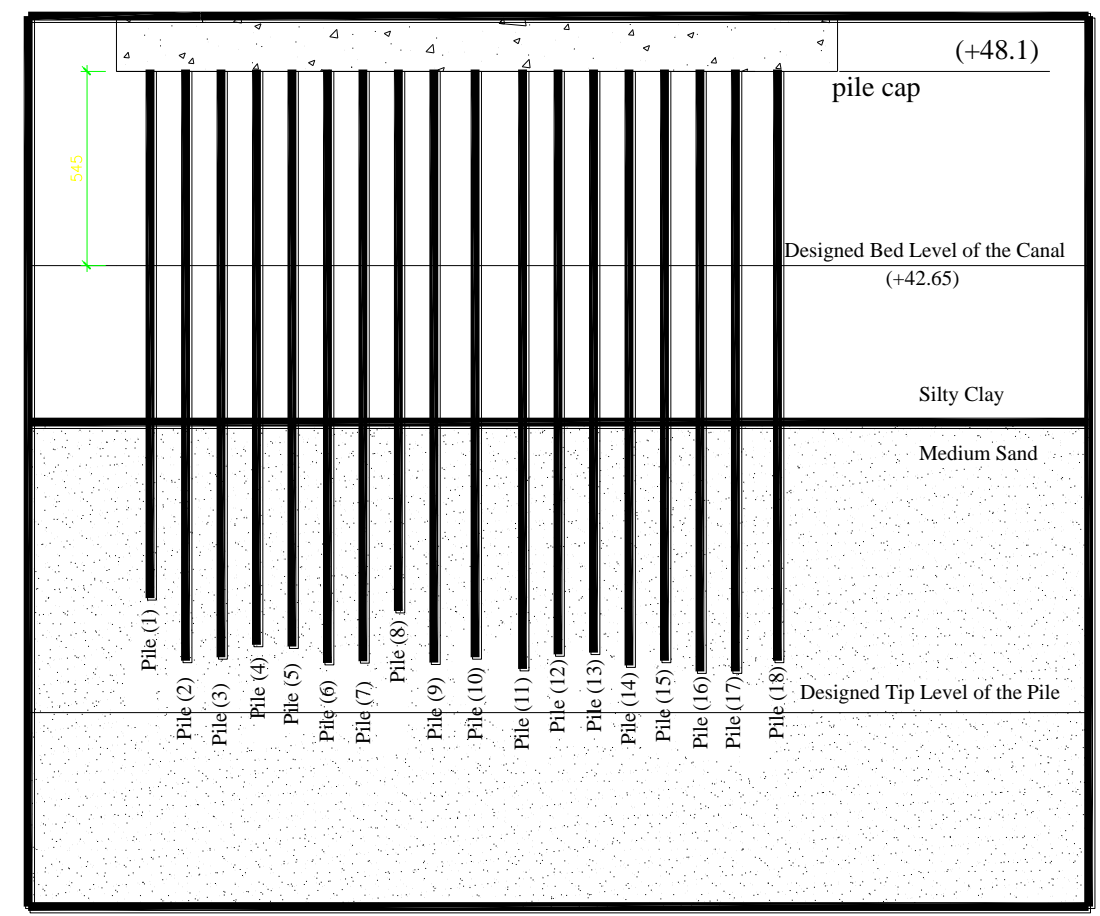

Fig. 9 The embedded length of the driven piles of support no. 7

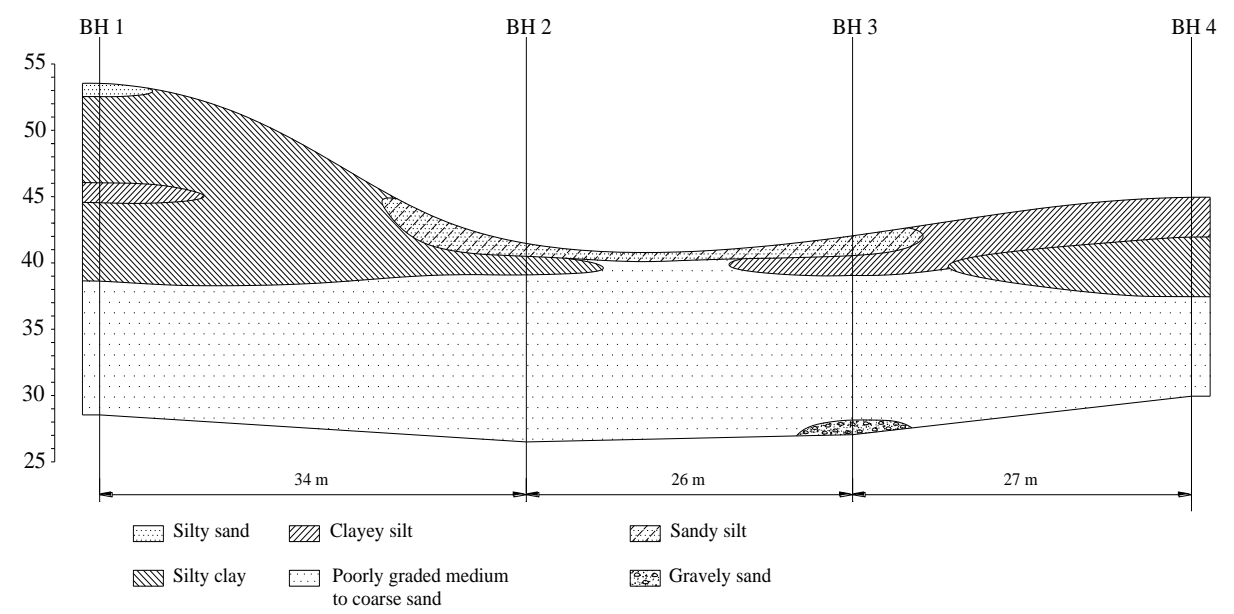

Fig. 10 Letheological section of soil stratification at cross section of the canal
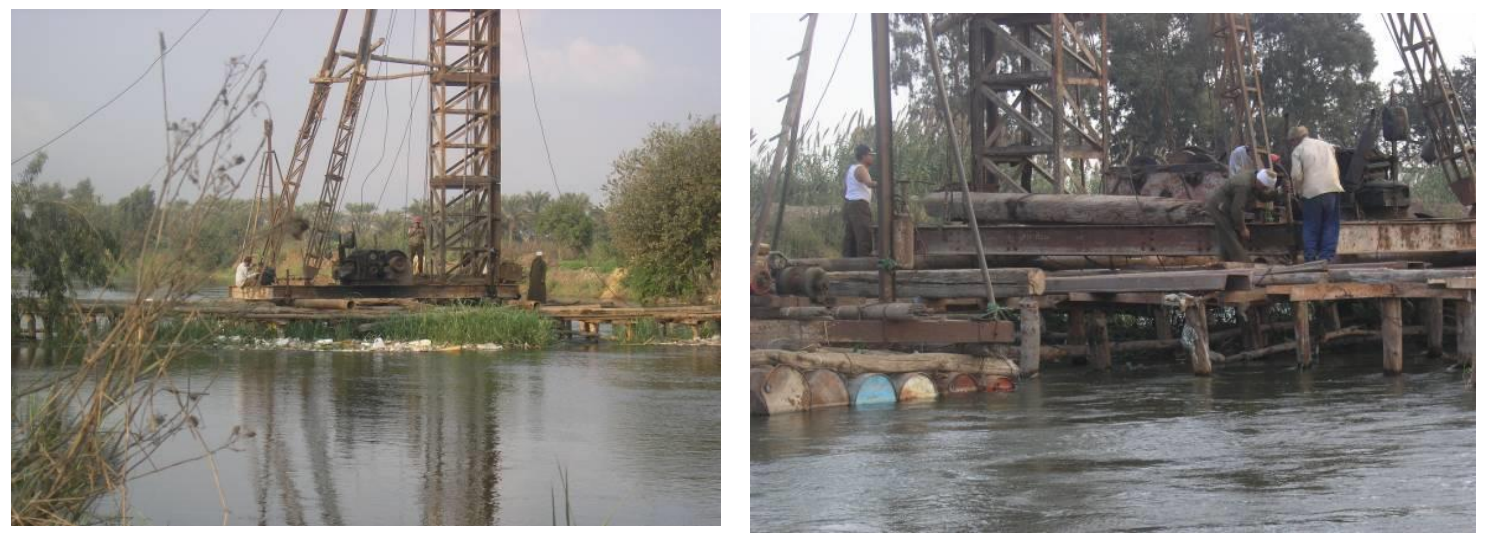

Fig. 11 Platform setup used to drive piles of bridges across water courses 


\section{STABILITY ANALYSIS}

The stability of the piles under the new conditions in the field was investigated using three criteria; the pile capacity, the buckling length, and the bending moment on the piles.

\subsection{The Pile Capacity}

The vertical load carrying capacity of each pile was estimated based on the embedded length of the pile using the Egyptian code for soil mechanics and foundation design and construction (Ministry of Housing and Infrastructures, 2008). The soil profile and characteristics are indicated in figure (12). The load carrying capacity was estimated using the smallest pile length in each pile group.

The ultimate load carrying capacity or the ultimate load resistance $\mathrm{Q}_{\mathrm{u}}$ of the pile is defined as the maximum load at which the pile continues to settle without increase of load. The load carrying capacity of pile is determined by dynamic formulae, static pile formulae, pile load test and/or the stress wave theory model solved by finite element or finite difference methods. In this paper, the static pile formulae are used as indicated below:

$$
\begin{aligned}
& \mathrm{Q}_{\mathrm{u}}=\mathrm{Q}_{\mathrm{b}}+\mathrm{Q}_{\mathrm{s}} \\
& \mathrm{Q}_{\mathrm{b}}=\mathrm{CN}_{\mathrm{c}} * \mathrm{~A}_{\mathrm{b}} \quad(\text { for cohesive soil) } \\
& \mathrm{Q}_{\mathrm{b}}=\mathrm{P}_{\mathrm{b}} \mathrm{N}_{\mathrm{q}} * \mathrm{~A}_{\mathrm{b}} \quad(\text { for cohesion less soil) } \\
& \mathrm{Q}_{\mathrm{s}}=\mathrm{K}_{\mathrm{HC}} * \mathrm{P}_{\mathrm{o}} * \tan \delta * \mathrm{~A}_{\mathrm{s}} \quad(\text { for cohesion less soil) } \\
& \mathrm{Q}_{\mathrm{s}}=\mathrm{C}_{\mathrm{a}} *\left(\mathrm{~A}_{\mathrm{s}}\right) \quad(\text { for cohesive soil }) \\
& \mathrm{Q}_{\mathrm{all}}=\mathrm{Q}_{\mathrm{u}} / \mathrm{F} . \mathrm{S}
\end{aligned}
$$

Where: $Q_{b}$ is ultimate bearing resistance, $Q_{s}$ is ultimate skin resistance, $C$ is soil cohesion, $\mathrm{N}_{\mathrm{c}}$ and $\mathrm{N}_{\mathrm{q}}$ are soil bearing factors, $A_{b}$ is bearing area of the pile, $\mathrm{P}_{b}$ is the effective soil stress at tip of the pile, $\mathrm{P}_{\mathrm{o}}$ is the effective soil stress at middle of the pile length, $\mathrm{K}_{\mathrm{HC}}$ is the percentage of lateral pressure to effective vertical pressure on pile sides, $\delta$ is soil/concrete friction angle, $\mathrm{C}_{\mathrm{a}}$ is the soil/concrete adhesion coefficient, $A_{s}$ is the shaft area, $Q_{a l l}$ is the allowable working load resistance, and FS is the factor of safety.

The allowable working load of the pile with a length equal to the embedded length was estimated for three cases. The first case is the allowable working load assuming full penetration of the piles and the scour taking place around them. Table (1) shows the estimated allowable working load of each pile at each support before and after scour and the reduction percent of the design allowable load. The second case is the allowable working load assuming piles refusal taking place and no scour around them.
Table (2) shows the estimated allowable working load of each pile at each support before and after refusal and the reduction percent of the design allowable load. The third case is the allowable working load assuming both piles refusal and scour around them taking place. Table (3) shows the estimated allowable working load of each pile at each support before and after scour and refusal and the reduction percent of the design allowable load. It could be shown from tables 1, 2, and 3 that the reduction in the allowable working load of the piles due to scour only ranges between $0.0 \%$ and $31.4 \%$, due to refusal only ranges between $12.6 \%$ and $35.4 \%$, and due to both refusal and scour ranges between $29.2 \%$ and $52.1 \%$.

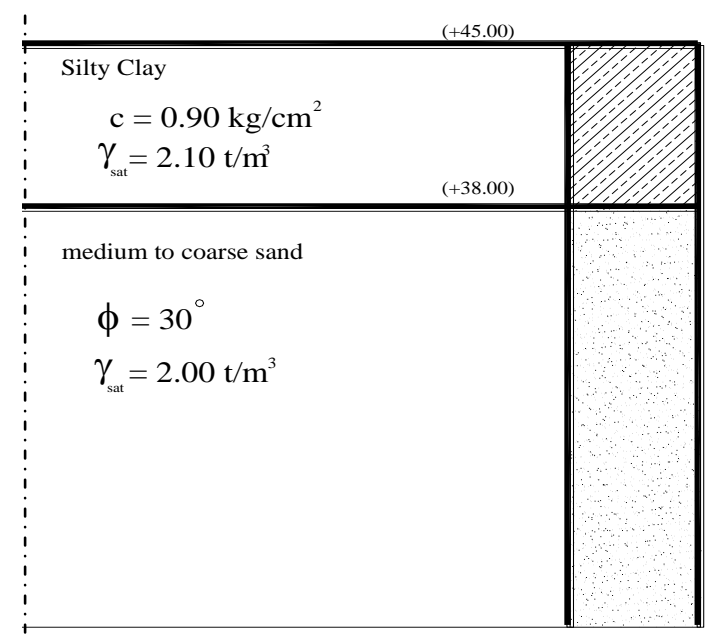

Fig. 12 Soil profile and soil characteristics at the site

\subsection{Effect of The Scour on Buckling Length}

For the supports in the water $(2,3,4,5,6$, and 7) the scour around the piles increased their free length and consequently their slender ratio. According to the Egyptian code for design of the reinforced concrete structures (Ministry of Housing and Infrastructures, 2009), slender columns are the ones with slender ratio more than 10 but should not exceed 23 and should be designed to resist additional bending moment due to buckling according to equation (7) (Ministry of Housing and Infrastructures, 2009).

$$
M_{a d d}=P \times \lambda_{t}^{2} \times \frac{t}{2000}
$$

Where:

$$
\begin{array}{ll}
\text { Madd } & =\text { Additional moment due to buckling } \\
\mathrm{P} & =\text { Axial load } \\
\lambda \mathrm{t} & =\text { Slender ratio } \\
\mathrm{t} & =\text { Pile width }
\end{array}
$$


The buckling length, slender ratio, and additional bending moment on the piles were calculated before and after the scour around the piles has taken place. The results are shown in table (4). From the table it could be seen that the slender ratio of the piles before buckling for all the supports were more than 10 and less than 23. This required an additional bending moment equal to $1.67 \mathrm{mt}$ applied on the pile cross sections. After the scour around the piles has taken place, the slender ratio increased for the piles in supports no. 3, 4, 5, and 6. For the pile in support 3, the additional bending moment increased by $35 \%$. However, for the piles in supports no. 4, 5, and 6 the slender ratio exceeded the limit defined the Egyptian code which is 23 which means that the piles are unsafe in buckling.

\subsection{Effect of The Scour on Moment Due to Lateral Load}

The lateral loads due to the drag and brake forces were calculated considering a drag force of 2.1 ton at half of the water depth and brake force of 1.75 ton at the pile head. Figure (13) indicates the schematic diagram of the lateral forces applied on the piles. The scour increased the moment due to the lateral loads on the piles. Table (5) shows the free length of the pile and the resulting moment on each pile for each support after the scour has taken place. The maximum normal stresses on the pile cross section due to normal load and bending moment were calculated for each pile before and after the scour. It was found that despite of increasing the moment because of the scour, the normal stresses were within the allowable limit and that the effect of the scour on the normal stresses on the pile cross section is limited.

Table 1, Reduction of the Allowable Working Load due to Scour Only

\begin{tabular}{||c|c|c|c|c|c|}
\hline $\begin{array}{c}\text { Support } \\
\text { No. }\end{array}$ & $\begin{array}{c}\text { Design } \\
\text { Embedded } \\
\text { Pile Length } \\
(\mathrm{m})\end{array}$ & $\begin{array}{c}\text { Design } \\
\text { Allowable } \\
\text { Working Load } \\
\text { (ton) }\end{array}$ & $\begin{array}{c}\text { Actual } \\
\text { Embedded } \\
\text { Pile Length } \\
(\mathrm{m})\end{array}$ & $\begin{array}{c}\text { Actual } \\
\text { Allowable } \\
\text { Working Load } \\
(\text { ton })\end{array}$ & $\begin{array}{c}\text { Reduction due } \\
\text { to Scour Only } \\
(\%)\end{array}$ \\
\hline \hline 2 & 12.55 & 46.18 & 12.55 & 46.18 & 0.0 \\
\hline 3 & 12.55 & 46.18 & 11.52 & 40.42 & 12.5 \\
\hline 4 & 12.55 & 46.18 & 9.82 & 31.69 & 31.4 \\
\hline 5 & 12.55 & 46.18 & 9.92 & 32.18 & 30.3 \\
\hline 6 & 12.55 & 46.18 & 10.67 & 35.94 & 22.2 \\
\hline 7 & 12.55 & 46.18 & 12.55 & 46.18 & 0.0 \\
\hline
\end{tabular}

Table 2, Reduction of the Allowable Working Load due to Refusal Only

\begin{tabular}{||c|c|c|c|c|c||}
\hline \hline $\begin{array}{c}\text { Support } \\
\text { No. }\end{array}$ & $\begin{array}{c}\text { Design } \\
\text { Embedded } \\
\text { Pile Length } \\
(\mathrm{m})\end{array}$ & $\begin{array}{c}\text { Design } \\
\text { Allowable } \\
\text { Working Load } \\
\text { (ton) }\end{array}$ & $\begin{array}{c}\text { Actual } \\
\text { Embedded } \\
\text { Pile Length } \\
(\mathrm{m})\end{array}$ & $\begin{array}{c}\text { Actual } \\
\text { Allowable } \\
\text { Working Load } \\
\text { (ton) }\end{array}$ & $\begin{array}{c}\text { Reduction } \\
\text { after Pile } \\
\text { Refusal Only } \\
(\%)\end{array}$ \\
\hline \hline 2 & 12.55 & 46.18 & 10.03 & 32.71 & 29.2 \\
\hline 3 & 12.55 & 46.18 & 9.43 & 29.82 & 35.4 \\
\hline 4 & 12.55 & 46.18 & 10.42 & 34.66 & 24.9 \\
\hline 5 & 12.55 & 46.18 & 11.97 & 42.89 & 7.12 \\
\hline 6 & 12.55 & 46.18 & 11.51 & 40.37 & 12.6 \\
\hline 7 & 12.55 & 46.18 & 9.75 & 31.35 & 32.1 \\
\hline \hline
\end{tabular}


Y. B. M. Heza, "Effect of Bed Scour and Pile Refusal on The Behavior of Piles in Water Courses in Egypt"

Table 3, Reduction of the Allowable Working Load due to both Refusal and Scour

\begin{tabular}{||c|c|c|c|c|c||}
\hline Support No. & $\begin{array}{c}\text { Design } \\
\text { Embedded Pile } \\
\text { Length (m) }\end{array}$ & $\begin{array}{c}\text { Design } \\
\text { Allowable } \\
\text { Working Load } \\
\text { (ton) }\end{array}$ & $\begin{array}{c}\text { Actual } \\
\text { Embedded Pile } \\
\text { Length } \\
(\mathrm{m})\end{array}$ & $\begin{array}{c}\text { Actual } \\
\text { Allowable } \\
\text { Working Load } \\
\text { (ton) }\end{array}$ & $\begin{array}{c}\text { Reduction after } \\
\text { Scour and Pile } \\
\text { Refusal } \\
(\%)\end{array}$ \\
\hline \hline 2 & 12.55 & 46.18 & 10.03 & 32.71 & 29.2 \\
\hline 3 & 12.55 & 46.18 & 8.40 & 25.40 & 45.0 \\
\hline 4 & 12.55 & 46.18 & 7.69 & 22.10 & 52.1 \\
\hline 5 & 12.55 & 46.18 & 9.34 & 29.40 & 36.3 \\
\hline 6 & 12.55 & 46.18 & 9.63 & 30.77 & 33.4 \\
\hline 7 & 12.55 & 46.18 & 9.75 & 31.35 & 32.1 \\
\hline
\end{tabular}

Table 4, Bending moment due to lateral forces and bending moment due to buckling

\begin{tabular}{||c|c|c|c|c|c|c|c||}
\hline $\begin{array}{c}\text { Support } \\
\text { No. }\end{array}$ & $\begin{array}{c}\text { Buckling } \\
\text { length } \\
\text { before } \\
\text { scour }(\mathrm{m})\end{array}$ & $\begin{array}{c}\text { Slender } \\
\text { ratio } \\
\text { before } \\
\text { scour }\end{array}$ & $\begin{array}{c}\text { Add. } \\
\text { Bending } \\
\text { moment } \\
\text { before scour } \\
(\mathrm{m} . \mathrm{t})\end{array}$ & $\begin{array}{c}\text { Buckling } \\
\text { length } \\
\text { after scour } \\
(\mathrm{m})\end{array}$ & $\begin{array}{c}\text { Slender } \\
\text { ratio } \\
\text { after } \\
\text { scour }\end{array}$ & $\begin{array}{c}\text { Add. } \\
\text { Bending } \\
\text { moment } \\
\text { after scour } \\
(\mathrm{m} . \mathrm{t})\end{array}$ & $\begin{array}{c}\text { Increase in } \\
\text { Add. } \\
\text { Bending } \\
\text { moment }(\%)\end{array}$ \\
\hline \hline 2 & 6.45 & 19.41 & 1.67 & 6.50 & 19.50 & 1.67 & 0.0 \\
\hline 3 & 6.45 & 19.41 & 1.67 & 7.50 & 22.50 & 2.25 & 35.0 \\
\hline 4 & 6.45 & 19.41 & 1.67 & 9.20 & 27.60 & Unsafe & --- \\
\hline 5 & 6.45 & 19.41 & 1.67 & 9.10 & 27.30 & Unsafe & -- \\
\hline 6 & 6.45 & 19.41 & 1.67 & 8.35 & 25.00 & Unsafe & --- \\
\hline 7 & 6.45 & 19.41 & 1.67 & 6.50 & 19.50 & 1.67 & 0.0 \\
\hline \hline
\end{tabular}
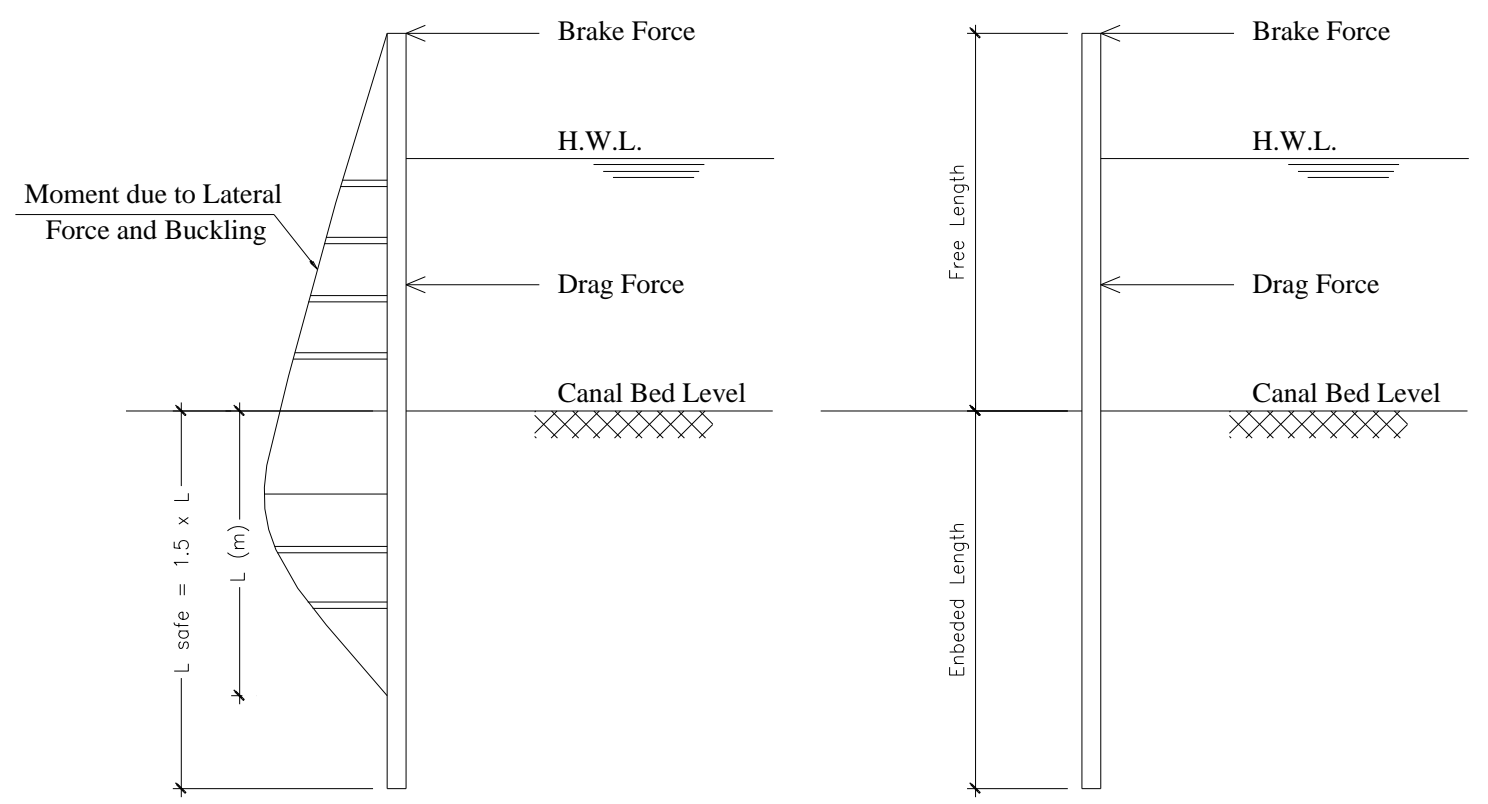

Fig. 13 Schematic diagram of the force inserted on the pile under investigation 
Table 5, Bending moment due to lateral forces

\begin{tabular}{||c|c|c|c|c||}
\hline $\begin{array}{c}\text { Support } \\
\text { No. }\end{array}$ & $\begin{array}{c}\text { Scour depth } \\
(\mathrm{m})\end{array}$ & $\begin{array}{c}\text { Total free } \\
\text { length }(\mathrm{m})\end{array}$ & $\begin{array}{c}\text { Total water } \\
\text { depth }(\mathrm{m})\end{array}$ & $\begin{array}{c}\text { Max. Bending moment } \\
(\mathrm{m} . \mathrm{t} .)\end{array}$ \\
\hline \hline 2 & -- & 5.45 & 5.95 & 15.79 \\
\hline 3 & 1.03 & 6.50 & 6.98 & 18.67 \\
\hline 4 & 2.73 & 8.20 & 8.68 & 23.43 \\
\hline 5 & 2.63 & 8.10 & 8.58 & 23.15 \\
\hline 6 & 1.88 & 7.35 & 7.83 & 21.05 \\
\hline 7 & -- & 5.45 & 5.95 & 15.79 \\
\hline
\end{tabular}

\section{DISCUSSION}

The case study presented in this paper is a good example on the negative effects of the lack of adequate technical investigations prior to construction. The lack of geotechnical investigation lead to the refusal of the piles before reaching the design foundation level. Table (2) shows that 4 out of 8 supports have a reduction of more than $20 \%$ of the pile capacity due to pile refusal. Furthermore, the lack of hydraulic investigation lead to a shorter embedment pile length because of scour and consequently longer buckling length. Table (1) shows that 3 out of 8 supports have a reduction of more than $20 \%$ of the pile capacity due to scour. The combination of the lack of both investigations at the same site made it worse. Table (3) shows that 6 out of 8 supports have a reduction of more than $20 \%$ of the pile capacity due to both scour and pile refusal. With some modification, a solution could have been made to stabilize the bridge in the case of scour only or pile refusal only. However, with both taking place, the solution will not be cost effective.

To solve the problem it was suggested either to add more bored piles around each support and construct a very rigid pile cap or to drive a box of steel sheet pile around the existing piles and fill it with concrete. Any of the two solutions will add a significant cost to the cost of the structure which could have been saved if the appropriate studies were made. However, the second solution is also not accepted hydraulically because the box around the piles will hinder significantly the flow of water in the channel and cause more scour around the supports and destabilize the structure.

\section{CONCLUSIONS AND RECOMMENDATIONS}

Using driven piles as supporting elements for bridges across water channels is a common practice in Egypt. However, the lack of adequate studies has caused problems in several sites. In this paper, a case study is presented to highlight the negative effects of the lack of adequate technical investigations. Neither adequate geotechnical nor hydraulic studies were made for the site. The lack of geotechnical study lead to missing the presence of very dense layer and consequently lead to pile refusal which meant construction of shorter piles. In addition, the platform used for the pile driving machine in the presence of water lead to the contraction of the water course cross section and the contraction gets worse by driving the reinforced concrete piles which in turn lead to a higher water velocity causing scour around the driven piles. It was shown that pile refusal and the scour reduced the allowable pile capacity by $29 \%$ to $52 \%$ of the original capacity. It was also shown that the slender ratio of the piles in 3 supports exceeded the limit defined the Egyptian code and are unsafe in buckling.

It is recommended to use a different method while constructing bridges across water courses to avoid the contraction of the water course due to the pile installation and consequently avoid the scour problem which destabilize the structures. Thorough technical investigations are highly recommended to be conducted before construction.

\section{REFERENCES}

[1] Broms, B.B., (1964) "Lateral resistance of pile in cohesive soil" ASCE, Journal of Soil Mechanics and Foundation Division, Vol.90, SM2, PP. 27-63.

[2] Broms, B.B., (1964) "Lateral resistance of pile in cohesionless soil" ASCE, Journal of Soil Mechanics and Foundation Division, Vol.90, SM2, PP. 123-156.

[3] Brown, D.A., Reese, L.C., and O'Neill, M.W. (1987) "Cyclic lateral loading of large scale pile group" Journal of Geotechnical Engineering, ASCE, 113(11), PP. 1326-1343.

[4] Dunnavant, T.W., and O'Neill, M.W. (1986) "Methodology for analysis of laterally loaded pile groups" Proceedings of Third International Conference on Numerical Methods in Offshore 
pilling, IFDP/LCPC, Nantes, France, PP. 303316.

[5] Ministry of Housing and Infrastructures (2008) "Egyptian code for soil mechanics and foundation design and construction" Part four; Deep Foundation.

[6] Ministry of Housing and Infrastructures (2009) "Egyptian code of design of reinforced concrete structures" .

[7] Matlock, H., and Reese, L.C. (1960) "Generalized solutions for laterally loaded piles" Journal of the Soil Mechanics and Foundations Division, ASCE, Vol.86, No.SM5, Proc. Paper 2626, Oct., PP. 63-91.

[8] Poulos, H.G., (1971 a) "behavior of laterally loaded piles: I-Single piles" Journal of Soil Mechanics and Foundation Division, ASCE, 97(5), PP. 711-731.

[9] Poulos, H.G., (1971 b) "behavior of laterally loaded piles: I-Pile groups" Journal of Soil
Mechanics and Foundation Division, ASCE, 97(5), PP. 733-751.

[10] Rhodes, J., and Trent, R., (1992) "An evaluation of Highway Flood damage Statistics" Proceedings of Hydraulic Engineering, Blatimore, Maryland, August 2-6, PP. 1082-1087.

[11] Smith, D.W., (1976) "Bridge Failures" Proceedings Institutions of Civil Engineering, part 1, No. 60, PP. 367-382.

[12] Zakaria, M.O., (2006) "Performance of pile group in sand under lateral load" $5^{\text {th }}$ International Engineering Conference, Elmansoura University, Faculty of Engineering, Sharm ElShekh, 27-31 March, PP. c-167 - c177.

[13] Yeo, W.K., (1998) "Field Investigation of Bridge Scours in Korea" 3 rd International Conference on Hydroscience and Engineering ICHE, Cottbus 31, August - 3 September. 